\title{
Making Ferronickel from Laterite Nickel Ore by Coal-Based Self-Reduction and High Temperature Melting Process
}

\author{
Chang Cao, Zhengliang Xue*, Hongjuan Duan \\ Key Laboratory for Ferrous Metallurgy and Resources Utilization of Ministry of Education, Wuhan University of \\ Science and Technology, Wuhan, China \\ Email: 752070228@qq.com, xuezhengliang@wust.edu.cn
}

Received 15 January 2016; accepted 16 April 2016; published 19 April 2016

Copyright @ 2016 by authors and Scientific Research Publishing Inc.

This work is licensed under the Creative Commons Attribution International License (CC BY).

http://creativecommons.org/licenses/by/4.0/

(c) (i) Open Access

\begin{abstract}
Based on the process of coal-based self-reduction and melting separation at high temperature, it was investigated that the effect of process factors on the reduction of iron and nickel oxide, the metal yield and the nickel content in ferronickel about the laterite nickel ore, was from Philippines and contented low nickel, high iron and aluminum. The results showed that if the $\mathrm{C} / \mathrm{O}$ mole ratio was not higher than 0.5 and the reduction temperature was kept as $1200^{\circ} \mathrm{C}$ and then increased up to $1500^{\circ} \mathrm{C}$, the metal could not separate from molten slag for the A series of experiments, which were only added $\mathrm{CaF}_{2}$. However, when the $\mathrm{C} / 0$ ratio was added up to $0.6-0.8$, the metal could separate well from the slag, and the yields of $\mathrm{Fe}$ and $\mathrm{Ni}$ increased gradually. But the nickel content in the metal declined from $1.79 \%$ to $1.34 \%$. When the $\mathrm{C} / 0$ ratio increased to 1.2 , and the temperature of melting products obtained at $1200^{\circ} \mathrm{C}$ and rose to $1550^{\circ} \mathrm{C}$, the separation of metal from slag could not be realized in $B$ group of tests, which were only added hydrated lime. However, when both of $\mathrm{CaF}_{2}$ and hydrated lime were added, the metal could separate from slag in $C$ group. In order to increase the content of nickel in the metal, it is necessary to restrain the reduction of iron oxide. When the $\mathrm{C} / 0$ mole ratio is 0.6 , the nickel content of metal could be $1.79 \%$, which was higher than the theoretical ratio $1.65 \%$ of $\mathrm{Ni} /(\mathrm{Ni}+\mathrm{Fe})$ of the latcritic nickel ore , but the yield of nickle was only $71.3 \%$.
\end{abstract}

\section{Keywords}

Low Grade Latcritic Nickel Ore, Coal-Based Self-Reduction, Ferronickel

\footnotetext{
"Corresponding author.
}

How to cite this paper: Cao, C., Xue, Z.L. and Duan, H.J. (2016) Making Ferronickel from Laterite Nickel Ore by Coal-Based Self-Reduction and High Temperature Melting Process. International Journal of Nonferrous Metallurgy, 5, 9-15. 


\section{Introduction}

Nickel was an important material for the production of austenitic stainless steel, heat resistant steel and nickel-based superalloy [1] [2]. For a long time, the nickel was mainly extracted from nickel sulfide ore [3] [4]. As the exhaustion of nickel sulfide ore in China, developing the resource of laterite nickel ore with low nickel grade but abundant reserves has been paid attention [5]-[8]. Laterite nickel ore is an ore by long-term weathering of ultrabasic rocks containing magnesium and iron silicate mineral. During the weathering process, $\mathrm{Mg}$ and $\mathrm{Fe}$ in the lattice of silicate were partially substituted by Ni gradually, to form the mineral deposit with different contents of nickel and gangue composition. The content of nickel less than $1.2 \%$ was called the low grade ore customarily, which had high iron content and more $\mathrm{Al}_{2} \mathrm{O}_{3}$ in the gangue. When the content of nickel was $1.2 \%$ to $1.8 \%$, the nickel laterite ore was called middle grade ore, and the nickel laterite ore, which the content of nickel was more than $1.8 \%$, was called the high grade nickel laterite which had low iron content and more $\mathrm{SiO}_{2}$ in the gangue. Laterite nickel ore was mainly distributed in tropical countries, within 30 degrees in north and south of the equator in the world. China mainly imported laterite nickel ore from Indonesia and Philippines, however, the Indonesian government went through the law about mineral and coal in 2009, and the law stipulated that the export of metal ores which included laterite nickel ore was prohibited from 2014. Therefore, this article mainly aimes to prepare ferronickel from low grade laterite nickel ore from Philippines by coal-based self-reduction process, which provides guidance for rational exploiting and utilizing of the low grade laterite nickel ore.

\section{Experimental Research Method}

\subsection{Raw Material Pretreatment and Its Physicochemical Properties}

The crude laterite nickel ore used in the study was from Philippines, which was crushed by jaw crusher, then grinded to $-0.125 \mathrm{~mm}$ with a ball mill and put in the oven to reserve after dried at $110^{\circ} \mathrm{C}$. The chemical composition was shown in Table 1. The Ni content was just $0.78 \mathrm{wt} \%$, the Fe content as high as $46.54 \mathrm{wt} \%$, and the content of $\mathrm{Al}_{2} \mathrm{O}_{3}$ in gangue reached $9.26 \mathrm{wt} \%$. This laterite nickel ore used in investigation is the low-nickel, high-iron, high-alumina and low-silica ore.

The X-ray diffraction spectrum of laterite nickel ore is shown in Figure 1. The Ni mainly exists in the form of $\mathrm{NiFe}_{2} \mathrm{O}_{4}$ and the $\mathrm{Fe}$ mainly exists in the form of $\mathrm{FeO}(\mathrm{OH})$ and $\mathrm{Fe}_{2} \mathrm{O}_{3}$.

The reductant in this study was anthracite, while the flux was calcium hydroxide and $\mathrm{CaF}_{2}$. The chemical composition was shown in Table 2. Both the anthracite and calcium hydroxide were sieved by $-0.125 \mathrm{~mm}$ sieve.

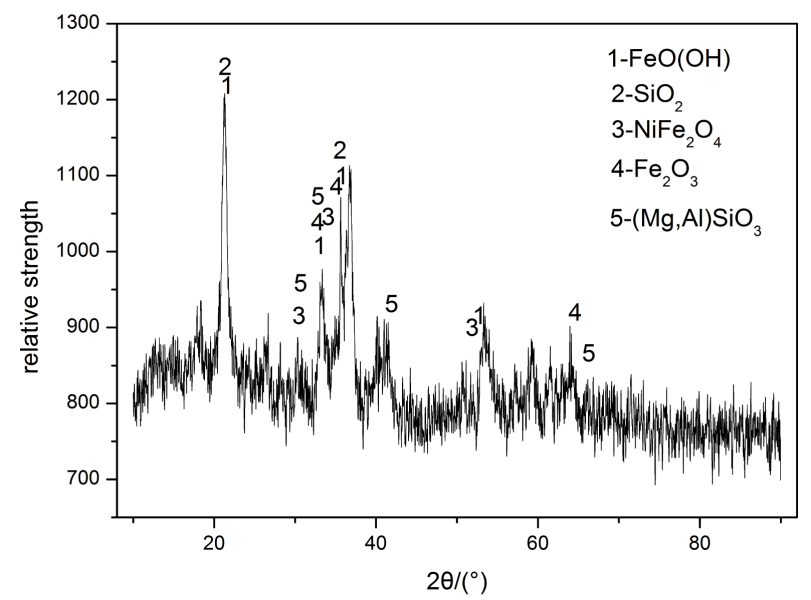

Figure 1. X-ray analysis diffraction patterns of the laterite nickel ore.

Table 1. Chemical compositions of latcritic nickel ore.

\begin{tabular}{ccccccccccccc}
\hline $\mathrm{TFe}$ & $\mathrm{FeO}$ & $\mathrm{Fe}_{2} \mathrm{O}_{3}$ & $\mathrm{CaO}$ & $\mathrm{MgO}$ & $\mathrm{SiO}_{2}$ & $\mathrm{Al}_{2} \mathrm{O}_{3}$ & $\mathrm{Ni}$ & $\mathrm{P}_{2} \mathrm{O}_{5}$ & $\mathrm{~S}$ & $\mathrm{Burning} \mathrm{Loss}$ \\
\hline 46.54 & 1.27 & 65.08 & 0.15 & 1.84 & 4.74 & 9.26 & 0.78 & 0.055 & 0.32 & 7.98 \\
\hline
\end{tabular}


Table 2. Chemical compositions of anthracite and calcium hydroxide.

\begin{tabular}{ccccccccc}
\hline Chemical Analysis & $\mathrm{C}$ & $\mathrm{S}$ & $\mathrm{SiO}_{2}$ & $\mathrm{Al}_{2} \mathrm{O}_{3}$ & $\mathrm{P}_{2} \mathrm{O}_{5}$ & $\mathrm{CaO}$ & $\mathrm{MgO}$ & Burning Loss \\
\hline Anthracite & 76.56 & 0.54 & 6.09 & 2.68 & 0.23 & 1.28 & 0.35 & - \\
Calcium Hydroxide & - & 0.041 & 0.56 & - & 0.005 & 67.52 & 4.56 & 26.72 \\
\hline
\end{tabular}

\subsection{Preparation of the Sample}

The reductant was anthracite, the mole ratio of $\mathrm{C} / \mathrm{O}$ was defined as the ratio of carbon in anthracite to oxygen of iron oxide and nickel oxide contained in the laterite nickel ore. In this work the $\mathrm{C} / \mathrm{O}$ was $0.5,0.6,0.8,1.0$ and 1.2. It was divided to $\mathrm{A}, \mathrm{B}, \mathrm{C}$ three groups according to the different additives. Only $\mathrm{CaF}_{2}$ was added in group A. Only calcium hydroxide was added in group B; both of them were added in group C. Calcium hydroxide was used to adjust the slag phase composition and its content was determined by the ratio of $\mathrm{CaO}$ and $\mathrm{Al}_{2} \mathrm{O}_{3}$ in the $12 \mathrm{CaO} ; 7 \mathrm{Al}_{2} \mathrm{O}_{3}$ formed in the slag phase. $\mathrm{CaF}_{2}$ was used to reduce the melting point of the slag phase. According to preliminary studies, the adding amount of $\mathrm{CaF}_{2}$ was $10 \%$ of the sum quantity of $\mathrm{CaO}, \mathrm{MgO}, \mathrm{SiO}_{2}$ and $\mathrm{Al}_{2} \mathrm{O}_{3}$ in slag phase.

After the laterite nickel ore, anthracite, calcium hydroxide and $\mathrm{CaF}_{2}$ were blending in proportion, then add a little of water as a wetting agent. The mixture was pressed into cylindrical specimens of $\varphi 20 \times 30 \mathrm{~mm}$, then putted it into stove and dried at $110^{\circ} \mathrm{C}$.

\subsection{Experimental Equipment and Methods}

Reduction experiments were carried out in $25 \mathrm{kVA}$ high temperature carbon tube furnace with rapid heating function, where the sample was heated to $1200^{\circ} \mathrm{C}$ in the rate of $120^{\circ} \mathrm{C}-150^{\circ} \mathrm{C} / \mathrm{min}$ and reduced for 10 minutes. It was then heated up rapidly to $1500^{\circ} \mathrm{C}$ or $1550^{\circ} \mathrm{C}$ and insulated for 20 minutes. After melting separation, it was cooled to below $600^{\circ} \mathrm{C}$ in the furnace. Removing the crucible to make the sample cool to room temperature in the air, the experimental sample number and the theoretical chemical composition of pressing block under the various ingredients scheme were shown in Table 3 and Table 4.

\section{The Principle of Reduction of Nickel and Iron Oxide}

The chemical reactions are as follows when $\mathrm{NiO}$ and $\mathrm{Fe}_{2} \mathrm{O}_{3}$ were reduced:

$$
\begin{gathered}
\mathrm{CO}_{2}+\mathrm{C}=2 \mathrm{CO} \\
\Delta \mathrm{G}^{\theta}=166550-171 T(\mathrm{~J} / \mathrm{mol}) \\
\mathrm{NiO}_{(\mathrm{s})}+\mathrm{C}=\mathrm{Ni}_{(\mathrm{s})}+\mathrm{CO} \\
\Delta \mathrm{G}^{\theta}=118050-169.36 T(\mathrm{~J} / \mathrm{mol}) \\
\mathrm{NiO}_{(\mathrm{s})}+\mathrm{CO}=\mathrm{Ni}_{(\mathrm{s})}+\mathrm{CO}_{2} \\
\Delta \mathrm{G}^{\theta}=-48500+1.64 T(\mathrm{~J} / \mathrm{mol}) \\
3 \mathrm{Fe}_{2} \mathrm{O}_{3(\mathrm{~s})}+\mathrm{CO}=2 \mathrm{Fe}_{3} \mathrm{O}_{4(\mathrm{~s})}+\mathrm{CO}_{2} \\
\Delta \mathrm{G}^{\theta}=-52131-41.0 T(\mathrm{~J} / \mathrm{mol}) \\
\mathrm{Fe}_{3} \mathrm{O}_{4(\mathrm{~S})}+\mathrm{CO}=3 \mathrm{FeO}_{(\mathrm{s})}+\mathrm{CO} \\
\Delta \mathrm{G}^{\theta}=35380-40.16 T(\mathrm{~J} / \mathrm{mol}) \\
\mathrm{FeO}_{(\mathrm{s})}+\mathrm{CO}=\mathrm{Fe}_{(\mathrm{s})}+\mathrm{CO} \\
\Delta \mathrm{G}^{\theta}=-22800+24.26 T(\mathrm{~J} / \mathrm{mol})
\end{gathered}
$$


Table 3. Sample number.

\begin{tabular}{cccc}
\hline Additive $\mathrm{C} / \mathrm{O}$ & $\mathrm{CaF}_{2}(\mathrm{~A})$ & Calcium Hydroxide $(\mathrm{B})$ & $\mathrm{CaF}_{2}$ and Calcium Hydroxide $(\mathrm{C})$ \\
\hline 0.5 & $1 \#(\mathrm{C} 0.5-1200-1500 \mathrm{~A})$ & - & - \\
0.6 & $2 \#(\mathrm{C} 0.6-1200-1500 \mathrm{~A})$ & - & - \\
0.8 & $3 \#(\mathrm{C} 0.8-1200-1500 \mathrm{~A})$ & - & $7 \#(\mathrm{C} 1.0-1200-1550 \mathrm{C})$ \\
1.0 & $4 \#(\mathrm{C} 1.0-1200-1500 \mathrm{~A})$ & $5 \#(\mathrm{C} 1.0-1200-1550 \mathrm{~B})$ & $8 \#(\mathrm{C} 1.2-1200-1550 \mathrm{C})$ \\
1.2 & - & $6 \#(\mathrm{C} 1.2-1200-1550 \mathrm{~B})$ & - \\
\hline
\end{tabular}

Table 4. Theoretical compositions of briquettes (wt $\%)$.

\begin{tabular}{cccccccccccccc}
\hline Number & $\mathrm{TFe}$ & $\mathrm{FeO}$ & $\mathrm{Fe}_{2} \mathrm{O}_{3}$ & $\mathrm{CaO}$ & $\mathrm{MgO}$ & $\mathrm{SiO}_{2}$ & $\mathrm{Al}_{2} \mathrm{O}_{3}$ & $\mathrm{Ni}$ & $\mathrm{CaF}_{2}$ & $\mathrm{~S}$ & $\mathrm{P}_{2} \mathrm{O}_{5}$ & $\mathrm{C}$ \\
\hline $1 \#$ & 41.70 & 1.14 & 58.30 & 0.25 & 1.68 & 4.79 & 8.53 & 0.697 & 1.53 & 0.097 & 0.070 & 6.79 \\
$2 \#$ & 41.00 & 1.12 & 57.30 & 0.27 & 1.66 & 4.80 & 8.43 & 0.688 & 1.51 & 0105 & 0.072 & 8.01 \\
$3 \#$ & 39.60 & 1.08 & 55.30 & 0.30 & 1.61 & 4.85 & 8.23 & 0.667 & 1.50 & 0.120 & 0.078 & 10.31 \\
$4 \#$ & 38.30 & 1.04 & 53.50 & 0.33 & 1.57 & 4.89 & 8.05 & 0.642 & 1.49 & 0.133 & 0.083 & 12.47 \\
$5 \#$ & 35.03 & 0.96 & 48.99 & 6.93 & 1.88 & 4.53 & 7.37 & 0.59 & - & 0.32 & 0.076 & 11.62 \\
$6 \#$ & 34.00 & 0.93 & 47.54 & 6.81 & 1.84 & 4.57 & 7.23 & 0.57 & - & 0.33 & 0.081 & 13.49 \\
$7 \#$ & 34.31 & 0.94 & 47.98 & 6.79 & 1.85 & 4.44 & 7.22 & 0.58 & 2.04 & 0.32 & 0.075 & 11.39 \\
$8 \#$ & 33.32 & 0.91 & 46.59 & 6.66 & 1.81 & 4.48 & 7.09 & 0.56 & 2.00 & 0.32 & 0.079 & 13.23 \\
\hline
\end{tabular}

The fixed carbon reacts with $\mathrm{CO}_{2}$ to generate $\mathrm{CO}$ that participate in indirect reduction of $\mathrm{NiO}$ and $\mathrm{Fe}_{2} \mathrm{O}_{3}$ [8], absorbing a lot of heat. The thermodynamic equilibrium curve of nickel oxide and iron oxide reduced by carbon was shown in Figure 2. Region $1\left(\mathrm{t}<400^{\circ} \mathrm{C}\right)$ is a stable region for $\mathrm{Fe}_{3} \mathrm{O}_{4}$ and $\mathrm{NiO}$; Region $2\left(400^{\circ} \mathrm{C}<\mathrm{t}<\right.$ $\left.656^{\circ} \mathrm{C}\right)$ is a stable region for $\mathrm{Fe}_{3} \mathrm{O}_{4}$ and $\mathrm{Ni}$; Region $3\left(656^{\circ} \mathrm{C}<\mathrm{t}<710^{\circ} \mathrm{C}\right)$ is a stable region for $\mathrm{FeO}$ and $\mathrm{Ni}$; $\mathrm{Re}-$ gion $4\left(\mathrm{t}>710^{\circ} \mathrm{C}\right)$ is a stable region for $\mathrm{Fe}$ and $\mathrm{Ni}$.

Theoretically, when the reduction temperature was controlled between $656^{\circ} \mathrm{C}-710^{\circ} \mathrm{C}$; the Ni in the ore could be reduced into metallic nickel, but iron existed in $\mathrm{FeO}$, so it could use magnetic separation to enrich nickel. However, it was hard to achieve these ideal results during actual operation. The main reason was as follows: 1) the reduction temperature of $656^{\circ} \mathrm{C}-710^{\circ} \mathrm{C}$ had not reached the temperature of rapid gasification reaction of carbon, so it was unable to realize the fully reduction of nickel oxide that only rely on solid-phase reduction between laterite nickel ore and coal; 2) because the nickel and iron were present as isomorphous, even if the full reduction of $\mathrm{NiO}$ did not change its lattice state, and it was difficult to separate the nickel and iron by physical separation [10]; 3) therefore, this study intended to improved the experimental temperature to accelerate the reduction of nickel and iron oxides, then separated the metal and gangue by high-temperature melting separation and to control the degree of reduction of iron oxide by controlling the distribution of carbon ratios.

\section{The Results and Discussion}

\subsection{The Morphology of Sample after Melting Separation}

After reduced at $1200^{\circ} \mathrm{C}$, and then heated to $1500^{\circ} \mathrm{C}$ or $1550^{\circ} \mathrm{C}$ to melting separation, the patterns were shown in Figure 3. Sample 1\# to Sample 4\# were group A that the additive was $\mathrm{CaF}_{2}$. Sample 1\# with carbon ratio of 0.5 had melted at $1500^{\circ} \mathrm{C}$, but the iron and slag were not separated (Figure 3(a)). After melting separation at $1500^{\circ} \mathrm{C}$, the iron and slag of Sample 2\#, 3\#, 4\# that carbon ratio was 0.6, 0.8, 1.0 separated well (Figures 3(b)-(d)). Sample 5\# (carbon ratio1.0) and Sample 6\# (carbon ratio1.2) were group B that the additive was slaked lime. In group B, when the melting separation temperature rose to $1550^{\circ} \mathrm{C}$, the iron and slag were not separated, but metal particles were wrapped by slag. After reduced at $1200^{\circ} \mathrm{C}$ and melted at $1550^{\circ} \mathrm{C}$, the iron and slag of group $\mathrm{C}$ that the additives were $\mathrm{CaF}_{2}$ and slaked lime separated well, as shown in Figure 3(g) and Figure 3 (h). 


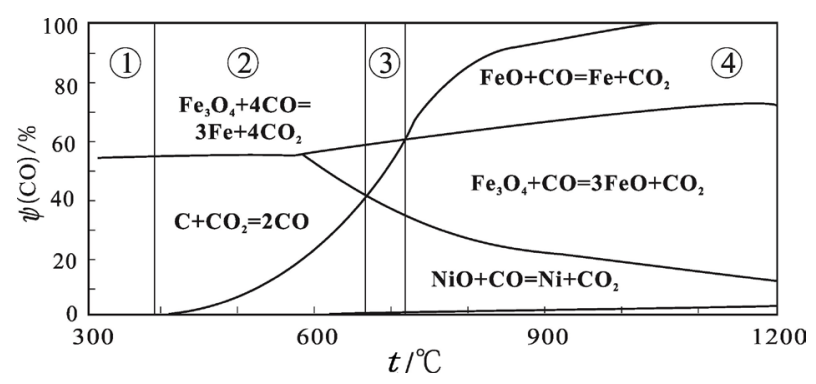

Figure 2. Thermodynamic balance diagram of iron oxide and nickel oxide reduced by carbon [9].

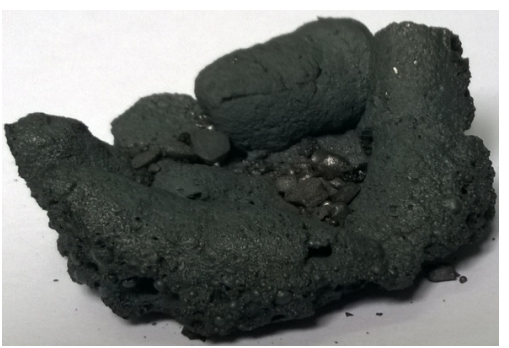

(a)

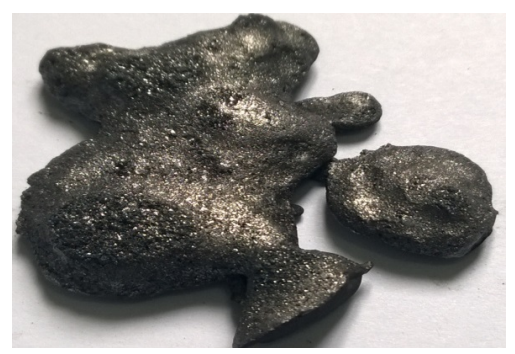

(c)

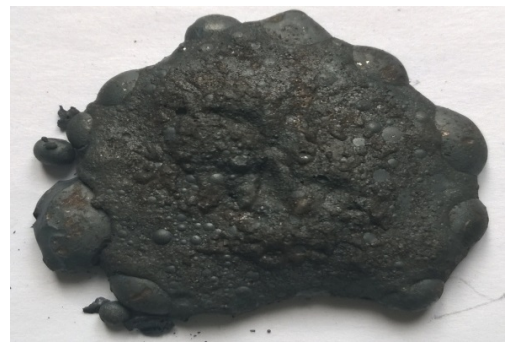

(e)

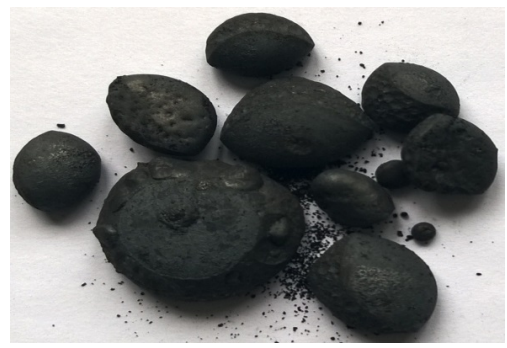

(g)

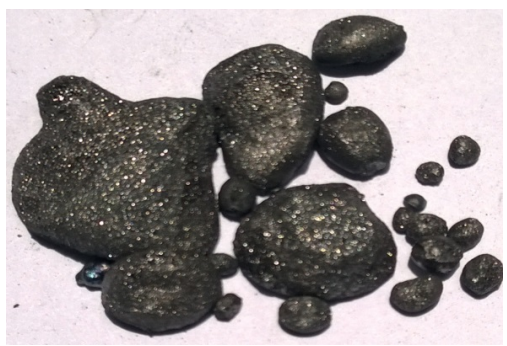

(b)

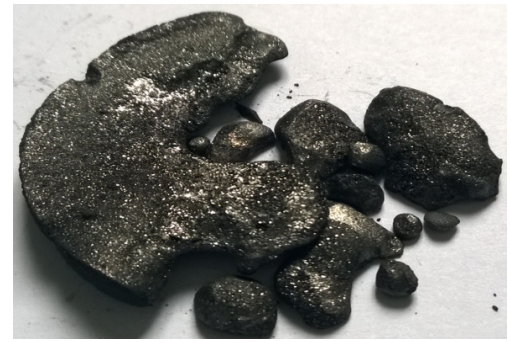

(d)

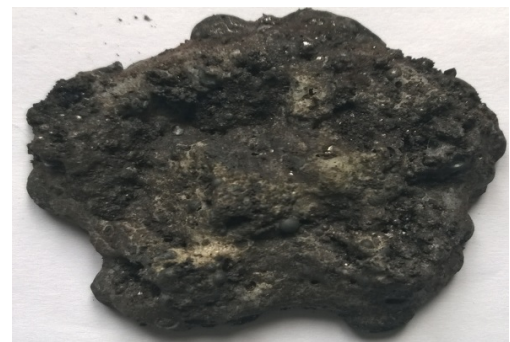

(f)

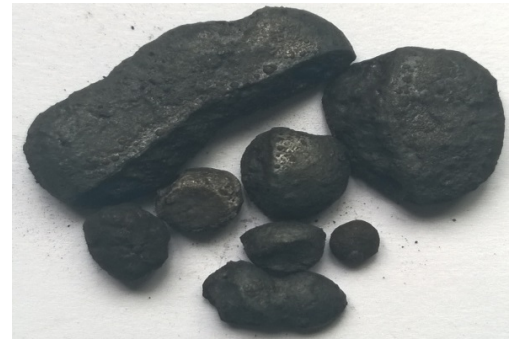

(h)

Figure 3. The patterns of samples reduced at $1200^{\circ} \mathrm{C}$ and meling separated at $1500^{\circ} \mathrm{C}$ and $1550^{\circ} \mathrm{C}$. (a) $1 \#$ the iron and slag was not separated; (b) 2\# the melted metal particles; (c) 3\# the melted metal particles; (d) 4\# the melted metal particles; (e) $5 \#$ metal particles was wrapped by slag; (f) 6\# metal particles was wrapped by slag; (g) $7 \#$ the melted metal particles; (h) $8 \#$ the melted metal particles. 
After comparing the figures, the conclusion could be obtained as follows: 1) in A group, when $\mathrm{C} / \mathrm{O}$ mole ratio was 0.5 , the samples had been melted after reduced at $1500^{\circ} \mathrm{C}$, while the slag and iron had not been separated. The main reason may be that the $\mathrm{C} / \mathrm{O}$ was too low, and the reduction of iron oxide was deficient. Moreover, the interfacial tension of slag and iron were reduced by large amounts of $\mathrm{FeO}$ that existed in slag which prevented the separation of slag and iron. When $\mathrm{C} / \mathrm{O}$ mole ratio increased to $0.6-1.0$, the reduction product could be separated significantly at $1500^{\circ} \mathrm{C} ; 2$ ) in $\mathrm{B}$ group which was added saked lime merely, when $\mathrm{C} / \mathrm{O}$ mole ratio was 1.0 , the separation of slag and iron cannot be realized at $1550^{\circ} \mathrm{C}$. But the reduction of iron oxide was sufficient which can be certified by particles of metallic iron wrapped on the slag. When $\mathrm{C} / \mathrm{O}$ mole ratio reached 1.2, the slag and iron mixed together at $1550^{\circ} \mathrm{C}$ and iron particles were fine, which indicated that superfluous $\mathrm{C}$ impede the aggregation of metallic iron. Therefore, we can conclude that when $\mathrm{C} / \mathrm{O}$ mole ratio is high and saked lime is added merely, the interfacial tension of slag and iron is depressed. It is not conductive to the separation of slag and iron; 3) in $\mathrm{C}$ group which were added $\mathrm{CaF}_{2}$ and saked lime simultaneously. Slag and iron can be separated adequately. Compared with $\mathrm{A}$ series added $\mathrm{CaF}_{2}$ only, it can be found that the surface of separated metal phase was smoother.

\subsection{The Chemical Compositions of Slag and Iron and Ni, Fe Yield of the Laterite Ore after Reduction and Melting}

The chemical compositions of slag and iron after reduction at $1200^{\circ} \mathrm{C}$ and melting at $1500^{\circ} \mathrm{C}$ (or $1550^{\circ} \mathrm{C}$ ) were shown in Table 5 and Table 6 respectively. The yield of Ni and Fe could be calculated by Equation (7) and Equation (8) respectively. And the results were shown in Table 5.

The yield of Ni: $\eta_{\mathrm{Ni}}=\frac{M_{\mathrm{Ni}}^{1}}{M_{\mathrm{Ni}}^{0}} \times 100 \%$

The yield of Fe: $\eta_{\mathrm{Fe}}=\frac{M_{\mathrm{Fe}}^{1}}{M_{\mathrm{Fe}}^{0}} \times 100 \%$

where $M_{\mathrm{Ni}}^{1}$ and $M_{\mathrm{Fe}}^{1}$ represent the quality of $\mathrm{Ni}$ and $\mathrm{Fe}$ in metallic particles after melted; $M_{\mathrm{N} i}^{0}$ and $M_{\mathrm{Fe}}^{0}$ represent the quality of $\mathrm{Ni}$ and $\mathrm{Fe}$ in lateritic ore with carbon compacts before reduction.

From the two tables, the following result can be concluded: 1) in A group, with the $\mathrm{C} / \mathrm{O}$ mole ratio changing from 0.6 to 1.0 , the rate of iron reduction increased gradually, while the content of $\mathrm{FeO}$ and $\mathrm{Ni}$ in slag decreased from $39.11 \%, 0.55 \%$ to $9.14 \%, 0.084 \%$ respectively (Table 6 ); 2 ) as for $\mathrm{C}$ group, with the $\mathrm{C} / \mathrm{O}$ mole ratio increasing from 1.0 to 1.2 , the content of $\mathrm{Ni}$ in metallic particles improved from $1.37 \%$ to $1.42 \%$ and the yield of $\mathrm{Ni}$ enhances from $88.74 \%$ to $92.12 \%$, while the yield of Fe changed little; 3 ) the desulfurization of slag can be improved when adding saked lime in compacts, the content of sulfur in metallic particles decreased observably.

Table 5. Chemical compositions of metal particles and the yield of nickel and iron (wt $\%)$.

\begin{tabular}{cccccccc}
\hline Number & $\mathrm{MFe}$ & $\mathrm{Ni}$ & $\mathrm{P}$ & $\mathrm{S}$ & $\mathrm{C}$ & $\eta_{N i}$ & $\eta_{\mathrm{Fe}}$ \\
\hline $2 \#$ & 89.65 & 1.79 & 0.042 & 0.627 & 4.967 & 71.3 & 59.96 \\
$3 \#$ & 89.42 & 1.39 & 0.011 & 0.641 & 5.167 & 71.4 & 77.61 \\
$4 \#$ & 87.33 & 1.34 & 0.011 & 0.651 & 6.045 & 88.2 & 95.91 \\
$7 \#$ & 88.73 & 1.37 & 0.013 & 0.23 & 2.78 & 88.74 & 96.29 \\
$8 \#$ & 89.91 & 1.42 & 0.013 & 0.22 & 2.82 & 92.12 & 97.69 \\
\hline
\end{tabular}

Table 6. Chemical compositions of the slags (wt $\%)$.

\begin{tabular}{ccccccc}
\hline Number & $\mathrm{SiO}_{2}$ & $\mathrm{Al}_{2} \mathrm{O}_{3}$ & $\mathrm{CaO} \%$ & $\mathrm{MgO} \%$ & $\mathrm{Ni} \%$ & 0.55 \\
$2 \#$ & 12.86 & 28.92 & 4.76 & 5.76 & 5.11 & 0.47 \\
$3 \#$ & 12.00 & 24.34 & 3.70 & 5.04 & 6.97 & 0.084 \\
$4 \#$ & 17.12 & 35.34 & 5.59 & 9.14 \\
\hline
\end{tabular}


Consequently, when increasing the content of $\mathrm{Ni}$ in the metal, the Inhibition of iron oxide reduction was needed. When the $\mathrm{C} / \mathrm{O}$ mole ratio was 0.6 , the nickel grade can be $1.79 \%$, which was higher than the theoretical ratio $1.65 \%$ of $\mathrm{Ni} /(\mathrm{Ni}+\mathrm{Fe})$ of the latcritic nickel ore, but the yield of nickle was only $71.3 \%$.

\section{Conclusions}

1) The laterite nickel ore used in this investigation is the low-nickel, high-iron, high-alumina and low-silica ore. The theoretical ratio $1.65 \%$ of $\mathrm{Ni} /(\mathrm{Ni}+\mathrm{Fe})$ of latcritic nickel ore is merely $1.65 \%$. To enhance the content of $\mathrm{Ni}$ in metal after reduction, the reduction of iron must be suppressed.

2) The self-reduction investigation of coal mixed briquettes indicates that when $\mathrm{C} / \mathrm{O}$ mole ratio is 0.5 , large amount of iron oxide have not been reduced to metallic iron, even with the method of high temperature melting after reduction, the metal phase and slag cannot be separated. In group $\mathrm{A}$, the added $\mathrm{CaF}_{2}$ is merely a flux, when $\mathrm{C} / \mathrm{O}$ mole ratio changes from $0.6,0.8$ to 1.0 ; the yield of metallic iron enhances from $59.96 \%, 77.61 \%$ to $95.91 \%$; the content of $\mathrm{Ni}$ in metallic particles decreases from $1.79 \%, 1.39 \%$ to $1.34 \%$; the yield of $\mathrm{Ni}$ increases gradually.

3) In group $\mathrm{C}$, the $\mathrm{CaF}_{2}$ and saked lime were added simultaneously. With the $\mathrm{C} / \mathrm{O}$ mole ratio improving from 1.0 to 1.2 , the content of $\mathrm{Ni}$ in metallic particles increases from $1.37 \%$ to $1.42 \%$ and the yield of $\mathrm{Ni}$ enhances from $88.74 \%$ to $92.12 \%$. But the yield of Fe has little changed. When saked lime added in the briquettes, the content of sulphur reduced significantly.

4) Low $\mathrm{C} / \mathrm{O}$ mole ratio restrains the reduction of ferric oxide and increases the content of $\mathrm{Ni}$ in metal, while the yield of Ni decreases.

\section{Acknowledgements}

The authors gratefully acknowledge the financial support for this work from the opening fund of State Key Laboratory for Ferrous Metallurgy and Resources Utilization of Ministry of Education, Wuhan University of Science and Technology (No. 2014QN21).

\section{References}

[1] Xun, Q.X. (2005) The Past and Future of Laterite Ores. China Nonferrous Metallurgy, No. 6, 1-8.

[2] Lv, X.W., Bai, C.G., Qiu, G.B., Hu, T. and Xie, H. (2011) Dehydrating and Sintering of Philippine Nickel Laterite. Canadian Metallurgical Quarterly, 50, 20-27. http://dx.doi.org/10.1179/000844311X552278

[3] Johnson, J.A., Cashmore, B.C. and Hockridge, R.J. (2005) Optimisation of Nickel Extraction from Laterite Ores by High Pressure Acid Leaching with Addition of Sodium Sulphate. Minerals Engineering, 18, 1297-1303. http://dx.doi.org/10.1016/j.mineng.2005.05.013

[4] Li, B., Wang, H. and Wei, Y.G. (2011) The Reduction of Nickel from Low-Grade Nickel laterite Ore Using a Solid-State Deoxidisation Method. Minerals Engineering, 24, 1556-1562. http://dx.doi.org/10.1016/j.mineng.2011.08.006

[5] Li, G.H., Shi, T.M., Rao, M.J., Jiang, T. and Zhang, Y.B. (2012) Beneficiation of Nickeliferous Laterite by Reduction Roasting in the Presence of Sodium Sulfate. Minerals Engineering, 32, 19-26. http://dx.doi.org/10.1016/j.mineng.2012.03.012

[6] Kim, J., Dodbiba, G., Tanno, H., Okaya, K., Matsuo, S. and Fujita, T. (2010) Calcination of Low-Grade Laterite for Concentration of Ni by Magnetic Separation. Minerals Engineering, 23, 282-288. http://dx.doi.org/10.1016/j.mineng.2010.01.005

[7] Kobayashi, I., et al. (2000) Direct Ironmaking Process Using Fine Ore and Coal. Asia Steel 2000, B, 132.

[8] Liu, Q.C. and Li, H.Y. (2006) Economic Research on Laterite Nickel Project. World Nonferrous Metals, No. 6, 68-69.

[9] Zhang, J.Y. (2007) Physical Chemistry of Metallurg. Metallurgic Industry Press, Beijing.

[10] Pan, C., Bai, C.G., Lv, X.W., et al. (2011) Study on Liquid Reduction of Philippines Nickeliferous Laterite Ore. Iron and Steel, No. 1, 24-28. 